Original Research Paper

\title{
Implementasi Model Pembelajaran Berbasis Masalah dan Pengaruhnya terhadap Perkembangan Karakter Mahasiswa
}

\author{
Supriadi $^{1}$, Wildan $^{1 *}$, Dwi Laksmiwati ${ }^{1}$ \\ ${ }^{1}$ Program Studi Pendidikan Kimia, Fakultas Keguruan dan Ilmu Pendidikan Universitas Mataram, Mataram, Indonesia
}

DOI: 10.29303 /jppipa.v6i1.323

Citation: Supriadi., Wildan., \& Laksmiwati, D. 2020. Implementasi Model Pembelajaran Berbasis Masalah dan Pengaruhnya Terhadap Perkembangan Karakter Mahasiswa. Jurnal Penelitian Pendidikan IPA (JPPIPA). 6(1). pp. 63-68

\author{
Article history \\ Received: October $15^{\text {th }} 2019$ \\ Revised: November $20^{\text {th }} 2019$ \\ Accepted: December 24 2019 \\ *Wildan: Program Studi \\ Pendidikan Kimia, Fakultas \\ Keguruan dan Ilmu Pendidikan \\ Universitas Mataram, Mataram, \\ Indonesia. \\ Email: \\ wildanfkip@unram.ac.id
}

\begin{abstract}
The purpose of this study was to describe the implementation of problem-based learning in environmental chemistry course and its effect on the development of students' character at Chemistry Education Programe, FKIP, Mataram University in the even semester of 2019/2020. This research was a pre-experimental research with pre-test post-test design, using a class consisting of 31 students. During class discussions, each group was very active in responding and defending opinions based on the references they had in the form of books, journals, and papers that they obtained from various sources. After being analyzed using the ANOVA test, an average score (mean) of students' characters after learning was 239.03 significantly higher than the mean before learning of 219.58. The character component includes attitudes, interests, values, and self-concepts significantly contribute to student character.
\end{abstract}

Keywords: Character development; environmental chemistry; problem based learning

Abstrak: Tujuan penelitian ini adalah mendeskripsikan pelaksanaan pembelajaran berbasis masalah dalam pembelajaran kimia lingkungan dan pengaruhnya terhadap perkembangan karakter mahasiswa Progaram Studi Pendidikan Kimia di FKIP Universitas Mataram pada semester genap tahun 2019/2020. Penelitian ini merupakan penelitian pra eksperimen dengan pre-test post-test design, menggunakan satu kelas yang terdiri dari 31 orang mahasiswa. Selama diskusi kelas, masing-masing kelompok sangat aktif untuk memberi tanggapan dan mempertahan pendapat berdasarkan referensi yang mereka punya baik berupa buku, jurnal, maupun makalah yang mereka peroleh dari berbagai sumber. Setelah dianalisis menggunakan uji anova, diperoleh skor rata-rata (mean) karakter mahasiswa sesudah pembelajaran sebesar 239,03 secara signifikan lebih tinggi dibandingkan dengan mean sebelum pembelajaran sebesar 219,58. Komponen karakter meliputi sikap, minat, nilai, dan konsep diri berkontribusi secara signifikan terhadap karakter mahasiswa.

Kata kunci: Kimia lingkungan; pembelajaran berbasis masalah; perkembangan karakter.

\section{Pendahuluan}

Perkembangan karakter menjadi salah satu fokus pemerintah pada semua jenis dan jenjang pendidikan di Indonesia. Saat ini pemerintah Indonesia melalui Menteri Pendidikan Nasional telah mengeluarkan kebijakan untuk mengintegrasikan pendidikan karakter ke dalam kurikulum (Sutjipto, 2011). Terdapat delapan potensi peserta didik yang perlu dikembangkan menurut Undang-undang, yaitu (1) manusia yang beriman dan bertakwa kepada Tuhan Yang Maha Esa, (2) berakhlak mulia, (3) sehat, (4) berilmu, (5) cakap, (6) kreatif, (7) mandiri, (8) menjadi 
warga Negara yang demokratis. Lima dari delapan potensi tersebut berkaitan dengan penguatan karakter.

Pemerintah telah mengeluarkan berbagai regulasi dan panduan teknis bagi sekolah dan perguruan tinggi dalam mengembangkan pembelajaran yang berbasis pengembangan karakter, namun kenyataannya lembaga-lembaga pendidikan yang ada masih belum maksimal dalam mengembangkan karakter peserta didik, baik melalui pembelajaran maupun kegiatan pendidikan lainnya. Sekolah dan pendidikan tinggi masih mengembangkan aspek kognitif melalui pembelajaran yang menjejali peserta didiknya dengan materi yang bersifat hafalan dengan strategi dan metode pembelajaran konvensional. Hal inilah yang menyebabkan lulusan persekolahan dan pendidikan tinggi tidak memberikan resonansi yang signifikan terhadap perkembangan kepribadian dan karakter peserta didik, sehingga kurang "berdaya saing" dibandingkan dengan negara-negara lain.

Perkembangan ilmu pengetahuan dan teknologi yang sangat cepat saat ini memaksa insan-insan pendidikan untuk merubah cara berpikir, bertindak, kebiasaan, penampilan, keberhasilan, nilai dan keyakinan, interaksi dan komunikasinya. Pelaksanaan pembelajaran harus mampu membentuk manusia secara utuh untuk membentuk manusia yang belajar sepanjang hayat (lifelong learners). Pendidikan yang diberikan tidak hanya memberi penekanan pada "aspek akademik" saja, tetapi harus mengembangkan pendidikan karakter yang menyangkut aspek sosial, emosi, kreativitas.

Karakter dapat terbentuk melalui proses berpikir seseorang yang akan menuntunnya mengambil sikap. Sikap yang diputuskan akan memotivasinya kepada suatu tindakan yang dilakukan secara konsisten dan terus-menerus, sehingga menjadi kebiasaan (Suyanto, 2009). Selaras dengan itu, Suharjana (2011) menyebutkan karakter sebagai sebuah cara berpikir, bersikap, dan bertindak yang menjadi ciri khas seseorang serta menjadi kebiasaan yang ditampilkan dalam kehidupan.

Pendidikan karakter menentukan cara berpikir dan berperilaku seseorang. Karakter yang baik dapat memberikan dorongan untuk berbuat baik, menyetujui seseorang yang setiap saat berbuat baik atau memiliki budi pekerti luhur. Hill (2005) memfokuskan karakter pada perilaku, sedangkan LeBlanc dan Gallavan (2009) menambahkan pada ranah afektif. Pendapat Hill, LeBlanc dan Gallavan diperluas oleh Zuchdi (2010) bahwa pendidikan karakter adalah sikap dan perilaku yang seharusnya dilakukan terhadap Tuhan Yang Mahaesa, masyarakat, negara, alam, dan diri sendiri.

Menurut Lickona (1991), karakter mempuyai empat dimensi, yaitu sikap, minat, nilai, dan konsep diri. Sikap merupakan respon seseorang suatu objek, situasi, konsep, atau orang. Sikap peserta didik ini penting untuk ditingkatkan (Popham, 1999). Dalam pembelajaran, perubahan sikap menjadi lebih positif seharusnya menjadi salah satu indikator keberhasilan pembelajaran. Untuk itu guru/dosen harus mampu mempersiapkan, melaksanakan, dan mengevaluasi pembelajaran akan sikap positif yang dapat berkembang secara maksimal.

Komponen kedua dari karakter adalah "minat". Minat merupakan suatu kecendrungan sikap yang terorganisir melalui pengalaman yang memotivasi seseorang untuk memperoleh objek khusus, aktivitas, pemahaman, dan keterampilan dengan tujuan perhatian atau pencapaian. Hal yang penting pada minat adalah intensitasnya. Keinginan yang kuat untuk belajar pada suatu matakuliah merupakan bagian dari minat. Minat didasari oleh rasa ingin tahu tentang sesuatu (Mardapi, 2013).

Komponen ketiga adalah"nilai". Nilai menurut Tyler (dalam Mardapi, 2013) merupakan objek, aktivitas, atau ide yang dinyatakan oleh individu dalam mengarahkan minat, sikap, dan kepuasan. Setiap indivdu belajar menilai suatu objek, aktivitas, dan ide sehingga objek ini menjadi pengendali penting minat, sikap, dan kepuasan. Untuk itu, setiap matakuliah harus mampu memperkuat nilai yang bermakna bagi peserta didik dalam memperoleh kebahagiaan dan memberi konstribusi positif terhadap masyarakat.

Komponen karakter berikutnya adalah "konsep diri". Konsep diri adalah keyakinan individu tentang dirinya, tentang kekuatan dan kelemahan yang ada pada dirinya, termasuk atribut dan sikap dirinya. Arah konsep diri bisa posititf atau negatif, dan intensitasnya bisa dinyatakan dalam suatu daerah kontinum, mulai dari yang rendah sampai yang tinggi. (Baumeister (1999). Menurut Agustini (2009) konsep diri adalah keseluruhan kesadaran atau persepsi seseorang tentang dirinya sendiri merupakan gambaran tentang diri atau konsep diri individu. Konsep diri berpengaruh kuat terhadap tingkahlaku seseorang. Dengan mengetahui konsep diri seseorang, akan lebih mudah meramalkan dan memahami tingkahlaku orang tersebut.

Salah satu model pembelajaran yang diasumsikan dapat mengembangkan karakter yang baik bagi peserta didik adalah model pembelajaran berbasis masalah, karena sesuai dengan karakteristiknya model pembelajaran ini antara lain masalah sebagai awal dari pembelajaran dan masalah tersebut merupakan masalah dunia nyata yang disajikan secara mengembangan, sehinga masalah tersebut menuntut mahasiswa untuk belajar menggunaakan berbagai pengetahuan yang berviariasi serta menuntut mahasiswa untuk kolaboratif, komunikatif, dan koperatif (Afandi dan Sajidan, 2017). Masalah yang digunakan dalam model pembelajaran berbasis masalah adalah masalah nyata yang terjadi 
pada lingkungan. Masalah tersebut diberikan kepada siswa agar belajar tentang berfikir kritis dan keterampilan pemecahan masalah, serta untuk memperoleh esensi dari pengetahuan dan konsep dari mata pelajaran. Dalam hal ini, siswa harus terlibat aktif dalam investigasi untuk memecahkan masalah yang mengintegrasikan antara keterampilan dan konsep dari berbagai isi materi pelajaran (Wardani, 2009).

Masalah tidak terstruktur adalah situasi awal dimana informasi yang diperlukan untuk menghasilkan sebuah solusi tidak tersedia dengan memadai dan situasi tersebut dapat dipecahkan dengan beragam cara. Penyajian masalah dalam pembelajaran berbasis masalah tersebut digunakan untuk memotivasi peserta didik dalam menemukan dan mengidentifikasi konsep atau prinsip yang dipelajari, mengembangkan kemampuan pemecahan masalah dan meningkatkan keterampilan belajar mandiri. Semakin dekat masalah yang disajikan tersebut dengan dunia nyata, maka semakin baik pula pembelajaran berbasis masalah (Afandi \& Sajidan, 2018).

Berdasarkan uraian di atas, maka tujuan penelitian ini adalah mendeskripsikan pelaksanaan model berbasis masalah dalam pembelajaaran kimia lingkungan dan pengaruhnya terhadap perkembangan karakter mahasiswa Progaram Studi Pendidikan Kimia di FKIP Universitas Mataram pada semester genap tahun 2019/2020.

\section{Metode}

Penelitian ini merupakan penelitian pra eksperimen dengan pre-test post-test design, menggunakan satu kelas yang terdiri dari 31 orang mahasiswa semester 6 (enam) tahun 2019/2020 yang mengikuti perkuliahan Kimia Lingkungan. Penelitian ini menerapkan pembelajaran berbasis masalah yang dilaksanakan 7 (tujuh) kali pertemuan setelah mahasiswa mengikuti ujian tengah semester. Sebelum pembelajaran dilaksanakan, mahasiswa diberikan inventori untuk mengetahui karakter awal mahasiswa.

Pada awal pertemuan dengan model pembelajaran berbasis masalah, dilakukan orientasi tentang model perkuliahan dan sistem penilaian yang akan diikuti dan mereview materi pokok pada mata kuliah kimia lingkungan yang didapat sebelumya. Materi pokok tersebut meliputi (1) pencemaran lingkungan udara, air, dan tanah, (2) sumber-sumber pencemaran, seperi sampah, kebakaran hutan, (3) pemanasan global, (4) plastik sebagai salah satu bahan pencemaran, dan (5) zat toksik (racun). Selain itu, mahasiswa juga diberi penjelasan tentang inventori yang akan mereka isi melaui google form yang akan dikirim melalui whatsapp (WA) di handpone masing- masing. Data yang terkumpul melalui inventori inilah yang dijadikan data karakter awal.

Instrumen digunakan untuk mengumpulkan data karakter, karena menurut Anderson (2001), karakter merupakan bagian dari ranah afektif yang metode pengumpulan datanya melalui observasi dan metode laporan-diri dengan asumsi bahwa yang mengetahui keadaan afektif (karakter) seseorang adalah dirinya sendiri. Metode laporan-diri ini penulis terjemahkan dengan menggunakan inventori untuk mengetahui karakter mahasiswa sebelum dan sesudah pembelajaran. Instrumen berupa inventori tersebut terdiri dari 40 butir pernyatan disusun berdasarkan 4 (empat) komponen karakter, yaitu (1) sikap yang terdri dari 9 butir, (2) minat terdiri dari 10 Butir, (3) nilai yang terdiri dari 9 butir dan (4) konsep diri terdiri dari 12 butir. Keempat puluh butir instrument tersebut valid dengan indeks berkisar antara 0,43-0,73, dengan koefisien reliabilitas 0,78 . Alternatif jawabannya dari 1 sampai 7, sehingga skor teoritis berkisar antara $40-$ 320. Analisis data dilakukan menggunakan ANOVA dengan SPSS 21(IBM SPSS Statistic 21) terhadap skor karakter sebelum dan sesudah pembelajaran berbasis masalah pada kuliah Kimia Lingkungan.

\section{Hasil dan Pembahasan}

\section{Deskripsi Pembelajaran Berbasis Masalah}

Perkuliahan kimia lingkungan pada penelitian ini dilakukan melalui 2 (dua) tahap. Tahap pertama dengan menggunakan waktu 7 (tujuh) kali pertemuan dengan tujuan agar mahasiswa lebih memahami konsep-konsep dasar pada matakuliah kimia lingkungan sebagai modal untuk mengikuti perkuliahan dengan pendekatan berbasis masalah. Pada tahap ini dibahas secara garis besar semua materi pada kimia lingkungan dengan membagikan buku ajar yang sudah disusun peneliti sebelumnya dengan metode tanya jawab, diskusi, dan diakhiri dengan pengumpulan data tentang karakter mahasiswa dengan inventori.

Pada tahap kedua, mahasiswa dibagi menjadi 6 kelompok diskusi dan dibagikan 6 (enam) permasalahan lingkungan yang disajikan dalam bentuk video, foto, berita/tulisan, kebijakan-kebijakan serta data-data yang berkaitan dengan masalah lingkungan disertai dengan masalah atau tugas-tugas yang akan didiskusikan baik di dalam kelas yang dilanjutkan di luar kelas sesuai kesepakatan kelompoknya. Diskusi kelompok dilakukan selama 3 (tiga) kali pertemuan, dan setiap kelompok harus melaporkan hasil diskusi kelompok dalam bentuk makalah dan power point sebagai bahan presentasi pada diskusi pleno.

Pada saat diskusi kelompok di kelas, tim dosen matakuliah yang terdiri dari 2 (orang) aktif berkeliling 
dan ikut duduk mendengar dan melihat jalannya diskusi. Dari hasil observasi terhadap jalanya diskusi kelompok. Kesan yang diperoleh selama diskusi kelompok, menunjukkkan sebagian besar mahasiswa sangat aktif bertanya, menjawab pertanyaan temannya, dan berpendapat dalam kelompoknya. Pada saat diskusi kelompok di kelas, sebagian masalah belum terjawab sehingga dilanjutkan di luar kelas. Pada waktu pengumpulan tugas kelompok, 4 (empat) kelompok mampu menyerahkan tugas makalah dan power point tepat waktu, kelompok lainnya menyerahkan tugas pada pertemuan berikutnya. Selanjutnya dilakukan diskusi kelas selama 3 (tiga) kali pertemuan, pada setiap pertemuan, dua kelompok mempresentasikan tugas kelompoknya masing masing yang diperoleh melalui undian pada pertemuan sebelumnya, kelompok lain memberikan masukan atau mengajukan pertanyaan.

Berdasarkan hasil pengamatan selama diskusi kelas, masing-masing kelompok sangat aktif untuk memberi tanggapan dan mempertahan pendapat berdasarkan referensi yang mereka punya baik berupa buku, jurnal, maupun makalah yang mereka peroleh dari berbagai sumber. Setelah selesai diskusi kelas, tim peneliti memberikan masukan terhadap jalannya diskusi.

Pada pertemuan terakhir, dilakukan ujian akhir semester dengan soal bentuk uraian yang mirip dengan bahan diskusi kelompok dan diberikan instrumen inventori untuk mengukur perkembangan karakter dalam bentuk google form melalui whatsapp di handphone mereka masing-masing dan jawaban mereka dijadikan data karakter setelah pembelajaran.

\section{Karakter Mahasiswa}

Informasi tentang karakter mahasiswa sebelum dan sesudah pembelajaran dengan pendekatan berbasis masalah (PBL) dalam penelitian ini dikumpulkan melalui inventori. Gambaran tentang skor karakter mahasiswa sebelum dan sesudah pembelajaran seperti pada tabel 1 berikut.
Tabel 1. Perbandingan Skor Karakter Sebelum dan Sesudah Pembelajaran

\begin{tabular}{llllll}
\hline Pre-Post & Mean & N & SD & Minimum & Maximum \\
\hline Skor awal & 219.58 & 31 & 15.7 & 185.00 & 241.00 \\
Skor akhir & 239.03 & 31 & 10.1 & 221.00 & 261.00 \\
\hline
\end{tabular}

Berdasarkan data pada tabel 1, skor sesudah pembelajaran lebih tinggi dibandingkan sebelum pembelajaran. Hal ini menunjukan pembelajaran berbasis masalah pada pembelajaran kimia lingkungan dapat meningkatkan skor mahasiswa. Hal ini berarti pula PBL dapat mengaktifkan, memotivasi mahasiswa. Dengan uji anova, diperoleh harga $F=31,860$ (sig. 00 ). Dengan demikian skor rata-rata (mean) sesudah pembelajaran sebesar 239,03 secara signifikan lebih tinggi dibandingkan dengan mean sebelum pembelajaran sebesar 219,58. Hasil pengujian dengan anova menghasilkan harga $\mathrm{F}=31.860$ (sig. 0.00).

Tabel 2. Hasil ANOVA Karakter sebelum dan Sesudah Pembelajaran

\begin{tabular}{lccccc}
\hline & $\begin{array}{c}\text { Sum of } \\
\text { Squares }\end{array}$ & df & $\begin{array}{c}\text { Mean } \\
\text { Square }\end{array}$ & F & Sig. \\
\hline $\begin{array}{l}\text { Between } \\
\text { Groups }\end{array}$ & 5864.66 & 1 & 5864.661 & 31.860 & .000 \\
$\begin{array}{l}\text { Within } \\
\text { Groups } \\
\text { Total }\end{array}$ & 11044.52 & 60 & 184.075 & & \\
\hline
\end{tabular}

Berdasarkan hasil tersebut dapat disimpulkan bahwa karakter mahasiswa sesudah pembelajaran secara signifikan lebih baik dibandingkan sebelum pembelajaran, yang berarti pula bahwa pembelajaran berbasis masalah pada matakuliah Kimia Lingkungan dapat mengembangkan karakter mahasiswa ke arah yang lebih positif.

Hasil tersebut sejalan dengan hasil komponen penyusun karakter, yaitu sikap, minat, nilai, dan konsep diri yang mana skor sesudah pembelajaran lebih tinggi dibandingkan sebelum pembelajaran. Perbedaan skor rata-rata sebelum dan sesudah pembelajaran secara signifikan berbeda yang ditunjukkan oleh harga F sebagai berikut.

Tabel 3. Harga F Komponen Penyusun Karakter Sebelum dan Sesudah Pembelajaran

\begin{tabular}{lllll}
\hline Karakter & Sikap & Minat & Nilai & Konsep Diri \\
\hline Harga F & 23,666 & 15,618 & 15,753 & 20,828 \\
& (Sig. 0,000) & (Sig. 0,000) & (Sig. 0,000) & (Sig. 0,000) \\
\hline
\end{tabular}

Dari hasil observasi selama pembelajaran, meningkatnya keaktifan mahasiswa pada diskusi kelompok maupun diskusi kelas selama mengikuti pembelajaran berbasis masalah disebabkan masalah yang menjadi tema/topik diskusi adalah masalahmasalah nyata dalam kehidupan sehari hari. Mereka aktif mencari sumber-sumber belajar karena mereka tahu yang aktif dalam diskusi akan menjadi bahan pertimbangan dalam penentuan nilai akhir. Dari hasil inventori, sebagaian besar responden sangat senang dengan pembelajaran, sehingga menimbulkan motivasi yang tinggi dalam belajar, sehingga nilai yang dicapai pada saat ujian akhir sangat memuaskan. Hal tersebut sesuai dengan pendapat Phee (2002) yang menyebutkan proses pemberian masalah serta proses mencari jawaban dalam pembelajaran dapat membantu 
siswa untuk lebih mudah memahami materi yang dipelajari. Hal yang sama disebutkan oleh Akcay (2009) yang mengatakan pembelajaran berbasis masalah dapat meningkatkan prestasi peserta didik karena menciptakan kondisi belajar yang membuat siswa aktif, sehingga siswa dapat membangun pengetahuannya serta dapat mengintegrasikan pelajaran yang didapatkan di sekolah dengan kehidupan sehari-hari. Pepper (2009) menyebutkan pembelajaran berbasis masalah dapat meningkatkan pengalaman belajar siswa, sedangkan Belt (2002) mengungkapkan bahwa pembelajaran berbasis masalah dapat meningkatkan motivasi siswa. Siswa dapat menjadi pembelajar yang lebih mandiri, pemecah masalah yang handal serta memiliki keterampilan profesional. Hasil penelitian ini sesuai pula dengan beberapa hasil penelitian yang melaporkan bahwa model pembelajaran berbasis masalah dapat meningkatkan hasil belajar tingkat tinggi. Hal ini pula yang menyebakan sikap, minat, nilai dan konsep diri mahasiswa meningkat segnifikan.

Hmelo-Silver \& Barrows (2006) menyatakan bahwa masalah yang dimunculkan dalam pembelajaran berbasis masalah tidak memiliki jawaban yang tunggal, artinya para mahasiswa harus terlibat dalam eksplorasi dengan beberapa jalur solusi. Keterlibatan mahasiswa dalam pembelajaran ini dapat membantu dalam mengembangkan kemampuan berpikir kritis dan terlibat penuh dalam proses pembelajaran. Selain itu, keterlibatan siswa pada kegiatan memecahkan masalah inilah yang membuat mahasiswa dapat mengembangkan kemampuan berpikir kritis. Chen (2013) menyebutkan pembelajaran berbasis masalah efektif dalam membantu peserta didik dalam proses belajar. Dalam pembelajaran berbasis masalah, peserta didik memperoleh keterampilan berpikir kreatif dan keterampilan professional. Pendapat di atas diperkuat oleh pendapat Echavarria (2010), bahwa pembelajaran berbasis masalah adalah strategi pedagogis yang berpusat pada peserta didik dengan mengkaji masalahmasalah dalam kehidupan sehari-hari dan bekerja dalam tim atau kelompok, dengan demikian dapat melatih peserta didik untuk bertanggung jawab dalam pembelajaran mereka sendiri dan mengubah peran pendidik menjadi fasilitator.

\section{Kesimpulan}

Berdasarkan hasil penelitian, dapat disimpulkan bahwa (1) implementasi pembelajaran berbasis masalah pada matakuliah Kimia Lingkungan di
Program Studi di Pendidikan Kimia FKIP Universitas Mataram, dengan tahapan penyajian masalah, diskusi kelompok, diskusi kelas, dapat berjalan dengan baik, dan dapat meningkatkan keaktifan mahasiswa dalam pembelajaran. (2) Implementasi pembelajaran berbasis masalah pada matakuliah Kimia Lingkungan di Prodi Pendidikan Kimia FKIP secara signifikan dapat mengembangkan karakter mahasiswa. (3) Komponen karakter meliputi sikap, minat, nilai, dan konsep diri secara signifikan berkontribusi terhadap karakter mahasiswa.

\section{References}

Afandi dan Sajidan, 2017. Stimulasi Ketrampilam Berpikir Tingkat Tinggi: Konsep dan Implikasi Dalam Pembelajan Abad 21. Surakarta: UPT UNS Press

Agustini, H. (2009). Psikologi Perkembangan: Pendekatan Ekologi Kaitannya dengan Konsep Diri dan Penyesuaian Diri pada Remaja. Bandung: Refika Aditama

Akcay, B. 2009. Problem base learning in science education. Journal of Turkish Education, 6 (1): 26-35

Andersen, Lorin. W. (1981). Assessing affective characteristic in the schools. Boston: Allyn and Bacon.

Anderson, L., and Krathwohl, D. (eds.) (2001). Assessing: A Revision of Bloom's Taxonomy. New York: Publishing Co, New York, US.

Baumeister, R. F. (Ed.) (1999). The self in social psychology. Philadelphia, PA: Psychology Press (Taylor \& Francis).

Chen, W.-H. (2013). Applying problembased learning model and creative design to conic-sections teaching. International Journal of Education and Information Technologies, 3(7), 73-80.

Mardapi, D. (2012). Pengukuran, penilaian, dan evaluasi pendidikan. Yogyakarta: Nuha, Medica.

Echavarria, M. V. (2010). Problem-based learning application in engineering. Revista EIA. scieloco.

Hill, T.A., 2005. Character First! Kimray Inc., http://www.charactercities.org/downloads/public ations/Whatischar acter.pdf

HmeloSilver, C. E., \& Barrows, H. S. (2006). Goals and strategies of a problem-based learning facilitator. The interdisciplinary Journal of Problembased Learning, 1(1), 21-39.

Leblanc, Patrice R \& Gallavan, Nancy P. 2009. Affective Teacher Education. New York: Association of Teacher Educattor 
Lickona, Thomas. (1991). Educating for character. New York: Bantam Books

Mardapi, D. (2013). Penilaian Karakter. Di dalam Bahan tulisan Penilaian Pendidikan Karakter Universitas Negeri Yogyakarta online: http://staff.uny.ac.id/sites/default/files/tmp/Penil aian_karakter.

Papalia. D. E \& S.W. Olds. (1993). A Child's World, Infancy Through Adolesence. USA: Mc. GrawHill, Inc.

Pepper, C. 2009. Problem Based Learning in Science. Issues in Educational Research, 9 (2): 128-141.

Phee, A.D.Mc. 2002. Problem base learning in initial teacher education: taking agenda forward. Journal of education enquiry, 3 (1): 60-74

Popham,W. J. 1999. Classroom assessment. Boston: Allyn and Bacon

Rianto, Y. 2010. Paradigma baru pembelajaran sebagai referensi bagi guru/pendidik dalam implementasi pembelajaran yang efektif dan berkualitas. Jakarta: Kencana Media Group

Suharjana. 2011. Model Pengembangan Karakter melalui Pendidikan Jasmani dan Olahraga. Yogyakarta: UNY Press.
Suyanto. 2009. Urgensi Pendidikan Karakter. Diakses pada tanggal 10 April 2011 dari http://www.mandikdasmen.depdiknas.go.id/we/ pages/urg ensi.html.

Wardani S., Antonius Tri Widodo, Niken Eka Priyani. (2009). Peningkatan Hasil Belajar Siswa Melalui Pendekatan Keterampilan Proses Sains Berorientasi Problem-Based Instruction. Jurnal Inovasi Pendidikan Kimia, (3) 1:391-399.

Zuchdi, Darmiyati, Prasetya, Zuhdan Kun, dan Masruri, Muhsinatun Siasah. 2010. "Pengembangan Model Pendidikan Karakter Terintegrasi dalam Pembelajaran Bidang Studi di Sekolah Dasar". Cakrawala Pendidikan. XXIX, edisi Dies Natalis UNY, hlm. 1- 12

Zuchdi, Darmiyati. 2010. Pendidikan Karakter. Yogyakarta: UNY. 